\title{
Probing the catalytically active species in POM-catalyzed DNA- model Hydrolysis
}

\author{
Frederico F. Martins, ${ }^{[a]}$ Dr. Ángel Sánchez-González, ${ }^{[a]}$ Jose Lanuza, ${ }^{[b, c]}$ Dr. Haralampos N. Miras, ${ }^{*[d]}$ \\ Prof. Xabier Lopez, ${ }^{[b, c]}$ Dr. Nuno A. Bandeira*[a] and Dr. Adrià Gil ${ }^{\star[a, e]}$
}
[a] MSc. F, F, Martins; Dr. A, Sánchez-González; Dr. N, A, Bandeira; Dr. A, Gil
BiolSI - Biosystems and Integrative Sciences Institute, Departamento de Química e Bioquímica, Faculdade de Ciências Universidade de Lisboa
8.5.53 C8 bdg, Campo Grande, 1749-016 Lisboa, Portugal
E-mail: a.gil@nanogune.eu
agmestres@fc.ul.pt
nuno.bandeira@ciencias.ulisboa.pt
[b] MSc. J, Lanuza; Prof. X. Lopez Lardizabal 3, 20018 Donostia-San Sebastián, Spain
[c] MSc. J, Lanuza; Prof. X. Lopez
Donostia International Physics Center (DIPC), Paseo Manuel de Lardizabal 4, 20018 Donostia-San Sebastián, Spain
[d] Dr. H, N, Miras
School of Chemistry
University of Glasgow
Joseph Black Building, Glasgow, G12 8QQ, UK
Email: Charalampos.Moiras@glasgow.ac.uk
[e] Dr. A. Gil
CIC nanoGUNE BRTA
Tolosa Hiribidea 76, E-20018, Donostia - San Sebastian, Euskadi, Spain
Supporting information for this article is given via a link at the end of the document.

Polimero eta Material Aurreratuak: Fisika, Kimika eta Teknologia Saila, Kimika Fakultatea, Euskal Herriko Unibertsitatea (UPV/EHU), Paseo Manuel de

\begin{abstract}
Phosphoester hydrolysis is an important chemical step in DNA repair. One archetypal molecular model of phosphoesters is para-nitrophenylphosphate (pNPP). It has been shown previously that the presence of molecular metal oxide $\left[\mathrm{Mo}_{7} \mathrm{O}_{24}\right]^{6-}$ may catalyse the hydrolysis of pNPP through the partial decomposition of polyoxomolybdate framework resulting in a $\left[\left(\mathrm{PO}_{4}\right)_{2} \mathrm{Mo}_{5} \mathrm{O}_{15}\right]^{6-}$ product. Real-time monitoring of the catalytic system using electrospray ionisation mass spectrometry (ESI-MS) provided a glance into the species present in the reaction mixture. Following up on the obtained spectrometric data, Density Functional Theory (DFT) calculations were carried out to characterise the hypothetical intermediate $\left[\mathrm{Mo}_{5} \mathrm{O}_{15}(\mathrm{pNPP})_{2}\left(\mathrm{H}_{2} \mathrm{O}\right)_{6}\right]^{6-}$ that would be required to form under the hypothesised transformation. Surprisingly, our results point to the dimeric $\left[\mathrm{Mo}_{2} \mathrm{O}_{8}\right]^{4-}$ anion resulting from the decomposition of $\left[\mathrm{Mo}_{7} \mathrm{O}_{24}\right]^{6-}$ as the active catalytic species involved in the hydrolysis of pNPP rather than the originally assumed $\left\{\mathrm{Mo}_{5} \mathrm{O}_{15}\right\}$ skeleton. A similar study was carried out involving the same species but substituting Mo by W. The mechanism involving W species showed a higher barrier and less stable products in agreement with the non-catalytic effect found in experimental results.
\end{abstract}

\section{Introduction}

Polyoxometalates (POMs) are negatively charged metal oxide clusters known since $1826^{1}$ (see Figure 1). Classical POM archetypes are mainly formed from $\mathrm{d}^{0}$ metal oxides made of $\mathrm{V}$, Mo or $\mathrm{W}$ which can undergo condensation reactions at acidic $\mathrm{pH}$ with subsequent loss of $\mathrm{H}_{2} \mathrm{O}^{2}$ Nevertheless, during the last years we can find examples of similar polyanionic nanostructures containing elements for the $f^{3-6}$ and $p$ groups..$^{7,8}$

During the last years, the applications of this family of compounds have been explored intensively and found their way in various fields such as the decontamination of water, ${ }^{9}$ flash memory devices, ${ }^{10}$ qubits, ${ }^{11}$ water splitting $^{12}$ as well as in biomedical research exploring their function as antiviral or antitumoral drugs. ${ }^{13-15}$ However, biomedical studies were still scarce in the latter case in the ' 90 s as discussed in the review of Rhule et al..$^{13}$ It was during the early-mid 2000 when systematic studies on the application of POMs to cancer treatment increased exponentially. ${ }^{14,16-20}$ Additionally, recent advances in the use of POMs for medical applications, their antitumor activity ${ }^{21}$ and their potential use to fight against bacterial antibiotic resistance ${ }^{22,23}$ have been reviewed by Bijelic et al. ${ }^{21,22}$ and Kortz et. al. ${ }^{23}$

According to Bijelic et al..$^{21,22}$ the proposed modes of antitumoral action of POMs involves a high number of biological targets: 1) Activation of cell death pathways, 2) Inhibition of angiogenesis, 3) Interaction with proteins or 4) DNA interaction among other mechanisms. On the other hand, the proposed mechanisms of action against bacteria involve: a) inhibition of both PBP2a and $\beta$-lactamases by POMs, b) POMs target P-type ATPases, c) impairment of the bacterial electron-transport chain (respiratory system) by POMs, d) POM-mediated increase of the reactive oxygen species level via oxidation, e) interaction of POMs with important membrane-anchored proteins and enzymes, f) the disruption of the bacterial cytoskeleton dynamics by POM-interactions with cytoskeletal elements, g) disruption of 
the bacterial cell wall leading to leakage of intracellular substances or $\mathrm{h}$ ) interaction with cytoplasmic elements or proteins that are anion-sensitive like nucleic acid-binding proteins. As discussed earlier, one of the processes described in the reviews of Bijelic et al. ${ }^{21,22}$ is the interaction of POMs with DNA to promote its phosphoester hydrolysis as artificial phosphoesterases. The study of this step is the focus of this work.
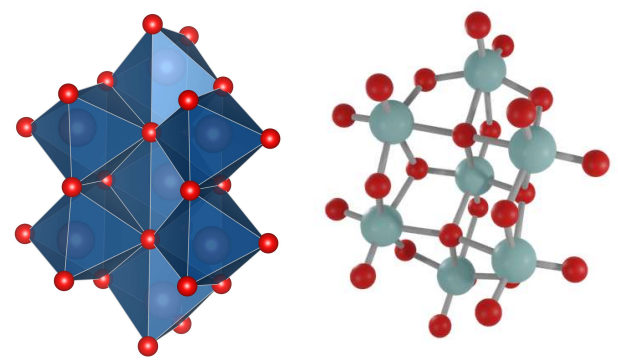

Figure 1. Polyhedral (left) and ball \& stick (right) structures of the $\left[\mathrm{Mo}_{7} \mathrm{O}_{24}\right]^{6}$ system studied in this work.

The phosphoester bond is produced when any hydroxyl group of the phosphoric acid react with hydroxyl groups of neighbouring molecules to form an ester bond. In the case of DNA, two bonds are formed from two hydroxyl groups of the phosphoric acid with the deoxyribose sugars forming the DNA strand to form the phosphodiester bond (see Scheme 1). These types of bonds are extremely stable and therefore play a very important role to maintain the integrity of the genetic code and the proper function of proteins. Consequently, nature has devised these links to maintain the connectivity of nucleosides in DNA, with remarkable kinetic stability: the half-life for hydrolysis of phosphoester bonds in DNA at neutral $\mathrm{pH}$ and $298 \mathrm{~K}$ is estimated to be 130 kyears. ${ }^{24}$ This resistance to hydrolysis is mainly due to the repulsion between the negatively charged backbone and the potential nucleophiles which are also negatively charged, consequently, an important Coulombic repulsion has to be surmounted in order to produce the hydrolysis, leading to high activation energy during the course of the phosphoester hydrolysis. ${ }^{25}$

This stability of the phosphoester can be overcome through a family of enzymes known as phosphoesterases. These catalysts play an important role in repairing DNA sequences ${ }^{26}$ allowing the rate increase of the phosphoester bond hydrolysis. Thus, the development of artificial catalysts which promote the phosphoester bond hydrolysis in reasonable time scales is an important research topic that has been explored extensively in the last 15 years. ${ }^{25,27-53}$ These artificial catalysts include $\mathrm{Cu}(\mathrm{II}),{ }^{54}$ $\mathrm{Zn}(\mathrm{II}){ }^{55}$ Lanthanide(III), ${ }^{56-58} \mathrm{Mo}(\mathrm{V} / \mathrm{VI})$ complexes ${ }^{25,35,36}$ and/or POM clusters. ${ }^{27-32,39-41,43,45-47}$

Particularly surprising is the catalysis of the phosphoester bond by polyoxoanions since an also negatively charged phosphate group will need to coordinate to them in order to facilitate a nucleophilic attack by water. A deeper understanding and rationalization of the catalytic mechanism involving POMs and chemical species with phosphoester bonds is inherently highly challenging.

In previous studies, Parac-Vogt et al. ${ }^{41,46}$ attempted to tap into the mechanistic action of $\left[\mathrm{Mo}_{7} \mathrm{O}_{24}\right]^{6-}\left(\left\{\mathrm{Mo}_{7}\right\}\right)$ in phosphoester hydrolysis employing model substrates and using several experimental techniques.

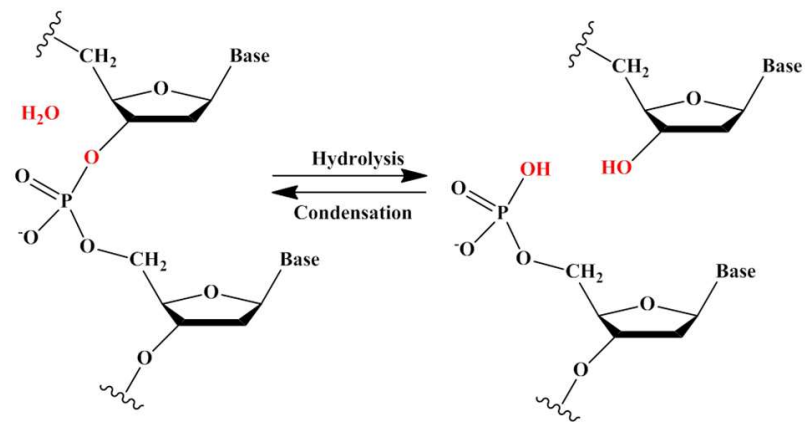

Scheme 1. Phosphodiester hydrolysis in DNA.

Their work consisted of the hydrolysis of paranitrophenylphosphate (hereafter named pNPP) in the presence of a $\left\{\mathrm{Mo}_{7}\right\}$ solution. ${ }^{27-30}$ The pNPP molecule is a typical model substrate of the phosphoester bond in DNA.

In their account, Parac-Vogt et al. ${ }^{27}$ clearly found that the hydrolysis was activated in the presence of $\left\{\mathrm{Mo}_{7}\right\}$ and subsequently proposed a set of transformation steps based on their findings, notably ${ }^{31} \mathrm{P}$ and ${ }^{1} \mathrm{H}$ and DOSY NMR, UV-Vis and RAMAN spectroscopies. It was found that during the course of this reaction a side product $\left[\mathrm{Mo}_{5} \mathrm{O}_{15}\left(\mathrm{PO}_{4}\right)_{2}\right]^{6-}\left(\left\{\mathrm{Mo}_{5}-\mathrm{PO}_{4}\right\}\right)$ anion was formed (see Figure 2) previously identified by Fischer and others. ${ }^{64}$

Based on this evidence the authors proposed two transformative steps () conducive to a hypothetical intermediate species $\quad\left[(\mathrm{pNPP})_{2} \mathrm{Mo}_{5} \mathrm{O}_{21}\right]^{4-} \quad\left(\left\{\mathrm{Mo}_{5}-\mathrm{pNPP}\right\}\right) \quad$ and $\left[(p N P P)_{2} \mathrm{Mo}_{12} \mathrm{O}_{36}\left(\mathrm{H}_{2} \mathrm{O}\right)_{6}\right]^{4-}($ Intermediates $\mathbf{A}$ and $\mathbf{B}$ on the original paper)
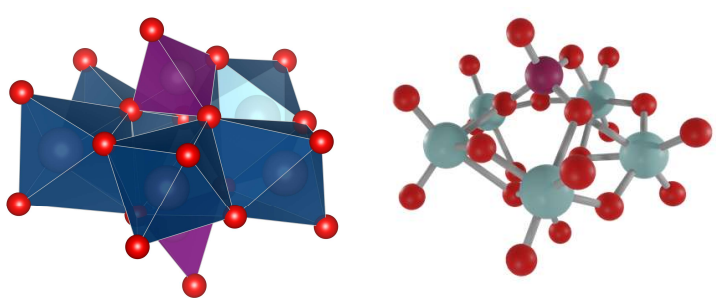

Figure 2. Polyhedral (left) and ball \& stick (right) representation of the $\left[\mathrm{Mo}_{5} \mathrm{O}_{15}\left(\mathrm{PO}_{4}\right)_{2}\right]^{6-}$ anion. 


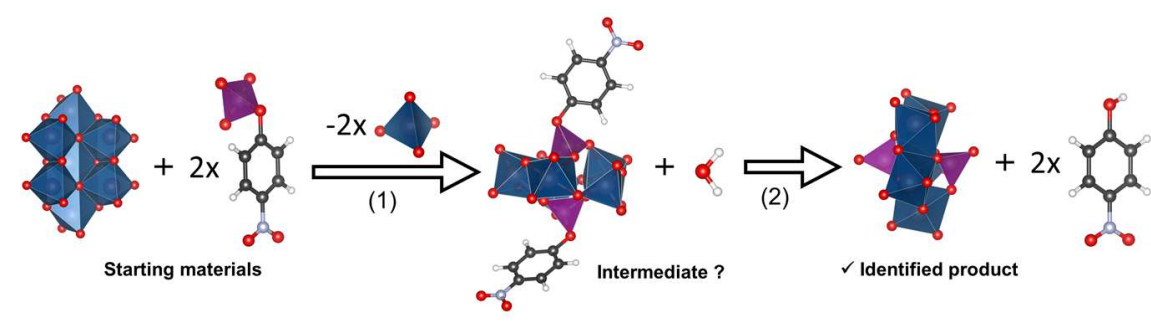

$(1)+(2):\left[\mathrm{Mo}_{7} \mathrm{O}_{24}\right]^{6-}+2\left[\mathrm{NO}_{2} \mathrm{PhOPO}_{3}\right]^{2-}+\mathrm{H}_{2} \mathrm{O} \rightarrow\left[\left(\mathrm{PO}_{4}\right)_{2} \mathrm{Mo}_{5} \mathrm{O}_{15}\right]^{6-}+2\left(\mathrm{NO}_{2} \mathrm{PhOH}\right)+2\left[\mathrm{MoO}_{4}\right]^{2-}$

Figure 3. Proposed chemical reactions (ref. 28) of the hydrolysis of pNPP catalysed by heptamolybdate. The phosphate groups are represented by purple hatched polyhedra.

One aspect is particularly striking in the previously reported work: The disparity in geometries between the $\left\{\mathrm{Mo}_{5}-\mathrm{PO}_{4}\right\}$ product and the $\left\{\mathrm{Mo}_{7}\right\}$ starting material. There is no simple obvious route from the latter to the former other than (1) the complete disassembly and subsequent re-assembly into $\left\{\mathrm{Mo}_{5}-\mathrm{PO}_{4}\right\}$ or (2) a significant structural rearrangement within the $\left\{\mathrm{Mo}_{5}\right\}$ framework.

The primal goal in this work is to unveil some of these obscure aspects in this particular reaction step. As such it was decided to revisit this work employing both experimental (ESI-MS) and computational approaches (DFT).

Herein we start out by analysing the $\left\{\mathrm{Mo}_{7}\right\}+$ pNPP reaction mixture using ESI-MS which can provide us with potential intermediate candidates and using these as a starting point to carry out a reaction path analysis in silico of the hydrolysis process.

Our new results highlight the fact that the $\left[\mathrm{Mo}_{5} \mathrm{O}_{15}\right]^{0}\left(\left\{\mathrm{Mo}_{5}\right\}\right.$, species which is the predecessor of the identified $\left.\left\{\mathrm{Mo}_{5}-\mathrm{PO}_{4}\right\}\right)$ is not the catalytically active species. We propose an alternative sequence of transformations where the original $\left\{\mathrm{Mo}_{7}\right\}$ reactant dissociates into two moieties: one dinuclear $\left[\mathrm{Mo}_{2} \mathrm{O}_{8} \mathrm{H}_{4}\right]\left(\left\{\mathrm{Mo}_{2}\right\}\right)$, and a pentanuclear $\left\{\mathrm{Mo}_{5}\right\}$ species. The former species is the agent that catalyses the hydrolysis whereas the latter will capture the resulting phosphate.

Additionally, the generation of the $\left[\mathrm{Mo}_{2} \mathrm{O}_{8} \mathrm{H}_{4}\right]$ and $\left[\mathrm{Mo}_{5} \mathrm{O}_{15}\right]$ species was corroborated by mass spectrometry experiments. Finally, the effect of solvent was considered not only with the dielectric continuum approach but also with a minimal number of explicit $\mathrm{H}_{2} \mathrm{O}$ molecules which provide a more accurate portrayal of the energy barrier corresponding to the pentacoordinate transition state.

\section{Results and Discussion}

\section{ESI-MS spectrometry}

In an effort to characterize further the clusters in solution and identify unambiguously the structural integrity and composition of the species formed during the course of the reaction, we employed high-resolution electrospray ionization mass spectrometry (ESI-MS) and monitored in real time the reaction mixture. ${ }^{59}$ The ESI-MS studies were performed in water/methanol (20:80). The speciation and fragment rearrangements were investigated as follows.

Sodium heptamolybdate, $\mathrm{Na}_{6}\left[\mathrm{Mo}_{7} \mathrm{O}_{24}\right]$ and pNPP were dissolved in aqueous solution and stirred at $50^{\circ} \mathrm{C}$ for approximately $30 \mathrm{~h}$. Aliquots were removed at noted time intervals throughout the reaction, diluted with methanol, and analysed using ESI-MS (the parameters for which were consistent throughout all runs). The first spectrum was recorded upon mixing the starting materials $(t=0)$ and after the reaction mixture had been stirred at $50^{\circ} \mathrm{C}$ for 1,3 and 30 hours, respectively. In both cases, the observation of the higher intensity set of distribution envelopes is due to the existence of the heptanuclear moiety, resulting from the combination of protons, counterions and solvent molecules. Additionally, transition metal clusters are generally susceptible to redox processes. The observed change of the oxidation state of the metal centres is due to the ionization and consecutive ion-transfer process of the charged species and has been observed previously on numerous occasions. ${ }^{60-62}$ In this case, the region of higher $\mathrm{m} / \mathrm{z}$ values is populated by a series of distribution envelopes assigned to -1 charged species and can be assigned to the $\left\{\mathrm{Mo}_{7}\right\}$ intact cluster (Figure 4, Table 1) with the corresponding distribution envelopes centred at c.a. 1103.27, 1225.25 and $1249.24 \mathrm{~m} / \mathrm{z}$. The intensity of the envelopes corresponding to the intact $\left\{\mathrm{Mo}_{7}\right\}$ cluster can be detected clearly the first 3 hours of the reaction while their relevant intensity gradually decreases to the point where cannot be detected any more $(t=30 \mathrm{~h})$. As expected, the peak centred at $217.90 \mathrm{~m} / \mathrm{z}$ can be assigned to the singly charged organic molecule of $\left[\mathrm{NO}_{2} \mathrm{C}_{6} \mathrm{H}_{4} \mathrm{PO}_{4} \mathrm{H}\right]^{-}$.

Interestingly, the lower region of $\mathrm{m} / \mathrm{z}$ values (ca. $300-1100$ ) revealed additional information regarding the building block units that can be generated in situ during the course of the catalytic reaction. The distribution envelopes centred at 304.77, 448.66, 470.64 and $510.72 \mathrm{~m} / \mathrm{z}$ values have been identified as trimeric $\left\{\mathrm{Mo}_{3}\right\}$ units associated with different number of counterions and solvent molecules while the envelope at $614.52 \mathrm{~m} / \mathrm{z}$ could be assigned to the tetrameric molybdenum moiety, $\left\{\mathrm{Mo}_{4} \mathrm{O}_{13} \mathrm{Na}\right\}^{-}$. Interestingly, two envelopes centred at 654.72 and $670.61 \mathrm{~m} / \mathrm{z}$ values have been identified as the $\left\{\mathrm{Mo}_{2}\right\}$ dimeric pNPP adducts revealing the ability to the lower nuclearity species to form hybrid complexes with the organic moiety. The higher $\mathrm{m} / \mathrm{z}$ region $(800-$ $1000 \mathrm{~m} / \mathrm{z}$ ) revealed the formation of penta-molybdodiphosphatebased, $\left[\mathrm{Mo}_{5} \mathrm{O}_{15}\left(\mathrm{PO}_{4}\right)_{2}\right]^{6-}$, derivatives which typically form in mildly acidic solutions containing molybdate and phosphate ions. ${ }^{63}$ However, it has been reported that the $\left[\mathrm{Mo}_{5} \mathrm{O}_{15}\left(\mathrm{PO}_{4}\right)_{2}\right]^{6-}$ anion does not induce the cleavage of the phosphoester bond in pNPP, even after prolonged reaction times ${ }^{28}$ which is an indication that the species forms in situ due to the presence of free $\mathrm{PO}_{4}{ }^{3-}$ anions originating from the cleavage of phosphate groups. Overall, the various species identified during the first hours of the reaction $(t=$ $0-3$ ), degrade over time and only dimeric and trimeric species can be identified after $30 \mathrm{hrs}$. These observations collectively increase our understanding of the rearrangement processes taking place in the reaction solution. 


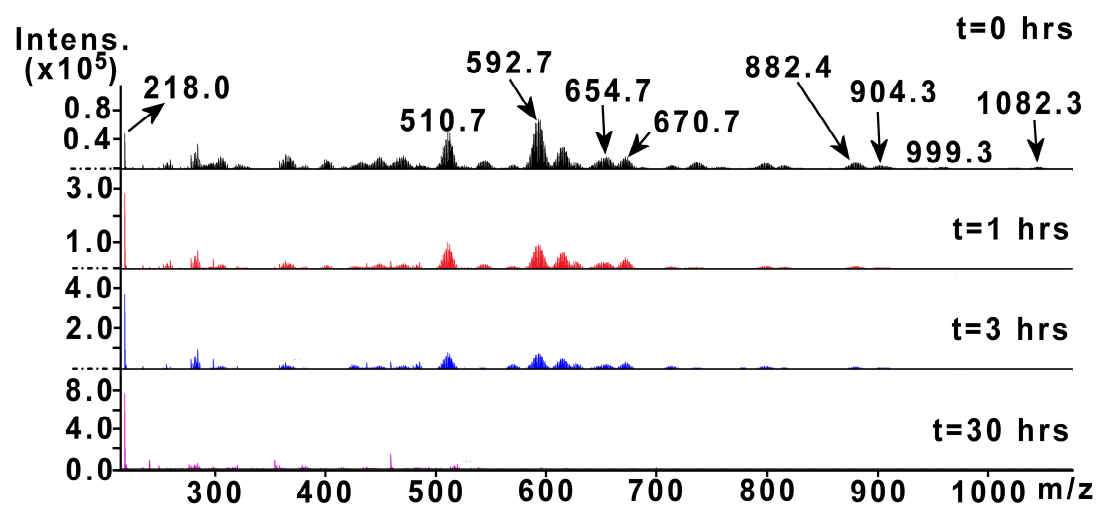

Figure 4. Negative mode electrospray ionisation mass spectrum (ESI-MS) of the reaction mixture in $\mathrm{H}_{2} \mathrm{O}: \mathrm{CH}_{3} \mathrm{OH}(20: 80)$.

In summary, several peaks were observed for $\left\{\mathrm{Mo}_{5}\right\}$ related species $(\mathrm{m} / \mathrm{z}=882.40$ to 999.35$)$ that incorporate either one or two phosphate groups. These species have been identified and reported previously in the literature. ${ }^{64}$ Interestingly, none of the identified species corresponds to an adduct of $\left\{\mathrm{Mo}_{7}\right\}(1103.27<$ $\mathrm{m} / \mathrm{z}<1249.24)$ or $\left\{\mathrm{Mo}_{5}\right\}$ type fragment with the pNPP anion as was hypothesised in the initial studies. ${ }^{28}$

Table 1. Representation of the experimentally identified and simulated $\mathrm{m} / \mathrm{z}$ values of distribution envelopes corresponding to the species in the reaction mixture.

\begin{tabular}{|c|c|c|c|}
\hline Exp. & Theor. & Charge & Chemical formula \\
\hline 218.00 & 217.98 & -1 & {$\left[\mathrm{NO}_{2} \mathrm{C}_{6} \mathrm{H}_{4} \mathrm{PO}_{4} \mathrm{H}\right]^{-}$} \\
\hline 304.77 & 304.74 & -1 & {$\left[\mathrm{Mo}_{2} \mathrm{O}_{7} \mathrm{H}^{-}\right.$} \\
\hline 448.66 & 448.70 & -1 & {$\left[\mathrm{Mo}_{3} \mathrm{O}_{10} \mathrm{H}\right]^{-}$} \\
\hline 470.64 & 470.65 & -1 & {$\left[\mathrm{Mo}_{3} \mathrm{O}_{10} \mathrm{Na}\right]^{-}$} \\
\hline 510.72 & 510.70 & -1 & {$\left[\mathrm{Mo}^{\mathrm{IV}} \mathrm{Mo}_{2}{ }_{2} \mathrm{O}_{9} \mathrm{Na}\left(\mathrm{H}_{2} \mathrm{O}\right)_{3} \mathrm{H}_{2}\right]^{-}$} \\
\hline 592.65 & 592.75 & -1 & {$\left[\mathrm{Mo}_{3} \mathrm{O}_{15}\left(\mathrm{H}_{2} \mathrm{O}\right)_{3} \mathrm{H}_{11}\right]^{-}$} \\
\hline 614.52 & 614.54 & -1 & {$\left[\mathrm{Mo}_{4} \mathrm{O}_{13} \mathrm{Na}\right]^{-}$} \\
\hline 654.72 & 654.61 & -1 & {$\left[\mathrm{Mo}^{\mathrm{IV}} \mathrm{Mo}^{\vee} \mathrm{O}_{7}\left(\mathrm{NO}_{2} \mathrm{C}_{6} \mathrm{H}_{4} \mathrm{PO}_{4}\right)(\mathrm{Na})_{5}\left(\mathrm{H}_{2} \mathrm{O}\right) \mathrm{H}^{-}\right.$} \\
\hline 670.61 & 670.71 & -1 & {$\left[\mathrm{Mo}^{\mathrm{V}} \mathrm{Mo}^{\mathrm{VI}} \mathrm{O}_{8}\left(\mathrm{NO}_{2} \mathrm{C}_{6} \mathrm{H}_{4} \mathrm{PO}_{4}\right)(\mathrm{Na})_{5}\left(\mathrm{H}_{2} \mathrm{O}\right) \mathrm{H}^{-}\right.$} \\
\hline 882.40 & 882.31 & -1 & {$\left[\mathrm{Mo}_{5} \mathrm{P}_{2} \mathrm{O}_{21} \mathrm{NaH}_{5}\right]^{-}$} \\
\hline 904.29 & 904.39 & -1 & {$\left[\mathrm{Mo}^{\mathrm{IV}} \mathrm{Mo}_{4}{ }_{4} \mathrm{P}_{2} \mathrm{O}_{21} \mathrm{NaH}_{4}\right]^{-}$} \\
\hline 999.35 & 999.36 & -1 & {$\left[\mathrm{Mo}_{5} \mathrm{P}_{2} \mathrm{O}_{23} \mathrm{Na}_{3}\left(\mathrm{H}_{2} \mathrm{O}\right) \mathrm{H}_{3}\right]^{-}$} \\
\hline 1017.47 & 1017.37 & -1 & {$\left[\mathrm{Mo}_{5} \mathrm{P}_{2} \mathrm{O}_{23} \mathrm{Na}_{3}\left(\mathrm{H}_{2} \mathrm{O}\right)_{2} \mathrm{H}_{3}\right]^{-}$} \\
\hline 1046.22 & 1046.35 & -1 & {$\left[\mathrm{Mo}^{\mathrm{IV}} \mathrm{Mo}_{4}{ }_{4} \mathrm{P}_{2} \mathrm{O}_{21} \mathrm{Na}_{5}\left(\mathrm{H}_{2} \mathrm{O}\right)_{3}\right]^{-}$} \\
\hline 1082.30 & 1082.37 & -1 & {$\left[\mathrm{Mo}^{\mathrm{IV}} \mathrm{Mo}_{4}{ }_{4} \mathrm{P}_{2} \mathrm{O}_{21} \mathrm{Na}_{5}\left(\mathrm{H}_{2} \mathrm{O}\right)_{5}\right]^{-}$} \\
\hline 1103.27 & 1103.34 & -1 & {$\left[\mathrm{Mo}_{3}{ }_{3} \mathrm{Mo}_{4}{ }_{4} \mathrm{O}_{24} \mathrm{Na}\left(\mathrm{H}_{2} \mathrm{O}\right) \mathrm{H}_{7}\right]^{-}$} \\
\hline 1225.25 & 1225.20 & -1 & {$\left[\mathrm{Mo}^{\vee} \mathrm{Mo}^{\mathrm{V}_{6}} \mathrm{O}_{24} \mathrm{Na}_{5}\left(\mathrm{H}_{2} \mathrm{O}\right)_{3} \mathrm{H}\right]^{-}$} \\
\hline 1249.24 & 1249.20 & -1 & {$\left[\mathrm{Mo}_{3}{ }_{3} \mathrm{Mo}_{4}{ }_{4} \mathrm{O}_{24} \mathrm{Na}_{6}\left(\mathrm{H}_{2} \mathrm{O}\right)_{3} \mathrm{H}_{2}\right]^{-}$} \\
\hline
\end{tabular}

\section{Computational studies}

Based on the evidence provided by the ESI-MS studies that a direct acid-base adduct of pNPP with $\left[\mathrm{Mo}_{7} \mathrm{O}_{24}\right]^{6-}$ is unlikely to take place, we proceeded initially to quantify the non-catalysed organic hydrolysis step in a computational study and used it as a reference point for the catalytic steps. Two kinds of mechanisms are traditionally proposed for the non-catalysed reaction. That is 1) the substrate-assisted mechanism in which the phosphate acts as a proton acceptor of an incoming water molecule and 2) the solvent-assisted mechanism in which there is a straightforward nucleophilic substitution of nitro-phenolate with water. In prior studies ${ }^{65}$ the most appropriate description of these two mechanisms entailed the use of explicit water molecules. For this reason, it was decided to include four in all the models as the best compromise between expediency and accuracy. The energy profiles of these mechanisms with the inactivated pNPP molecule are depicted in Figure 5. The values of $\Delta \mathrm{G}^{\neq}=+29.8 \mathrm{kcal} \mathrm{mol}^{-1}$ for the substrate assisted and $\Delta \mathrm{G}^{\ddagger}=+21.4 \mathrm{kcal} \mathrm{mol}^{-1}$ for the solvent assisted pathways are in line with previous computational studies. ${ }^{65}$

As the product that is detected in the Parac-Vogt studies ${ }^{28}$ is $\left[\mathrm{Mo}_{5} \mathrm{P}_{2} \mathrm{O}_{23}\right]^{6-}$ the natural step would be to reconstruct this phosphate templating reaction by performing the hydrolysis of grafted pNPP to reach this product. A reasonable starting species for this would be $\left[\mathrm{Mo}_{5} \mathrm{O}_{15}(\mathrm{pNPP})_{2}\right]^{4-}$. The production of the pentacoordinate phosphorus intermediate has an activation barrier that is $11 \mathrm{kcal} \mathrm{mol}^{-1}$ higher than the activation barrier of the uncatalysed substrate assisted reaction and $19 \mathrm{kcal} \mathrm{mol}^{-1}$ higher than the barrier for the solvent assisted pathway (see Figure 6). The POM activated pathways involve an $\mathrm{O}-\mathrm{H}$ bond cleavage from an incoming water molecule to one oxygen of the POM structure, resulting in a substrate-assisted type mechanism. For the $\left[\mathrm{Mo}_{5} \mathrm{O}_{15}(\mathrm{pNPP})_{2}\right]^{4-}$ the transition state leads to an intermediate $\lambda^{5}-$ phosphate $(\mathrm{V})$ containing structure that is a confirmed local minimum in energy. Subsequent searches for a solvent assisted mechanism with this $\left\{\mathrm{Mo}_{5}\right\}$ activator proved unsuccessful. This is probably due to the latent Brønsted acidity in polyoxoanions which makes proton transfers ubiquitous. Clearly, these results are inconsistent with the proposal set out in ref. 28 (Figure 3), i.e. that an $\left\{\mathrm{Mo}_{5}\right\}$ species is directly responsible for the higher rate of hydrolysis. The only adduct with pNPP that is observed in the ESIMS study given above is with a dinuclear entity $\left(\left[\mathrm{Mo}_{2} \mathrm{O}_{8}\left(\mathrm{NO}_{2} \mathrm{C}_{6} \mathrm{H}_{4} \mathrm{PO}_{4}\right)(\mathrm{Na})_{5}\left(\mathrm{H}_{2} \mathrm{O}\right) \mathrm{H}^{-}\right)\right.$. In the light of this observation it was decided to explore the catalytic ability of a dinuclear model with a reasonable formulation such as 
$\left[\mathrm{Mo}_{2} \mathrm{O}_{4}(\mathrm{OH})_{4}(\mathrm{pNPP})\right]^{2-}\left(\left\{\mathrm{Mo}_{2}\right\}\right)$ i.e. two edge-sharing octahedra capped with equatorial hydroxy groups, herein represented in Figure 7. Four explicit water molecules were included in this model to make it comparable to the organic reaction (Figure 5). Proton isomers of this species were pre-screened, and their energies are presented in the supporting information section.

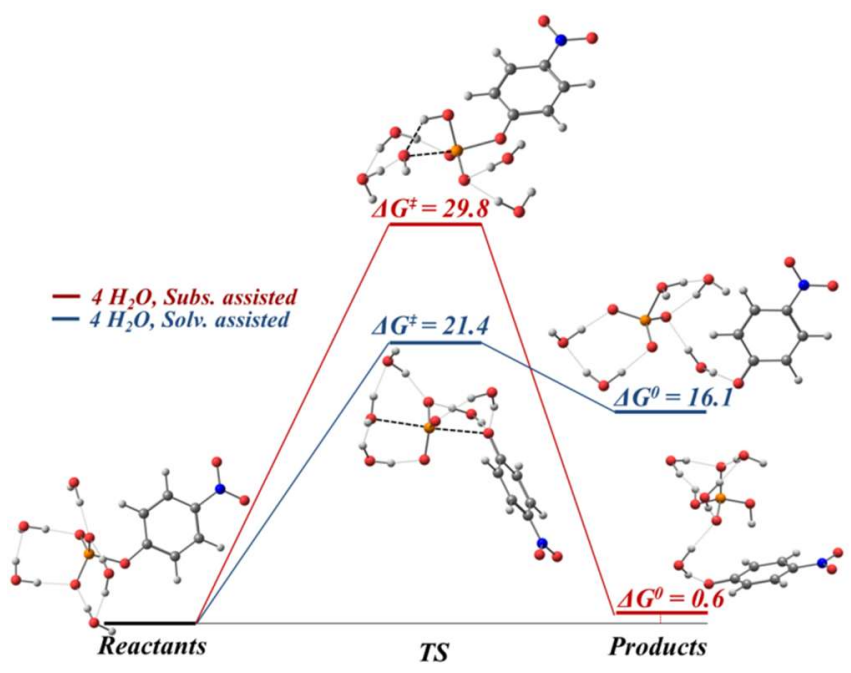

Figure 5. Reaction schemes for pNPP hydrolysis with no catalyst. Gibbs free energies in $\mathrm{kcal} \mathrm{mol}^{-1}$.

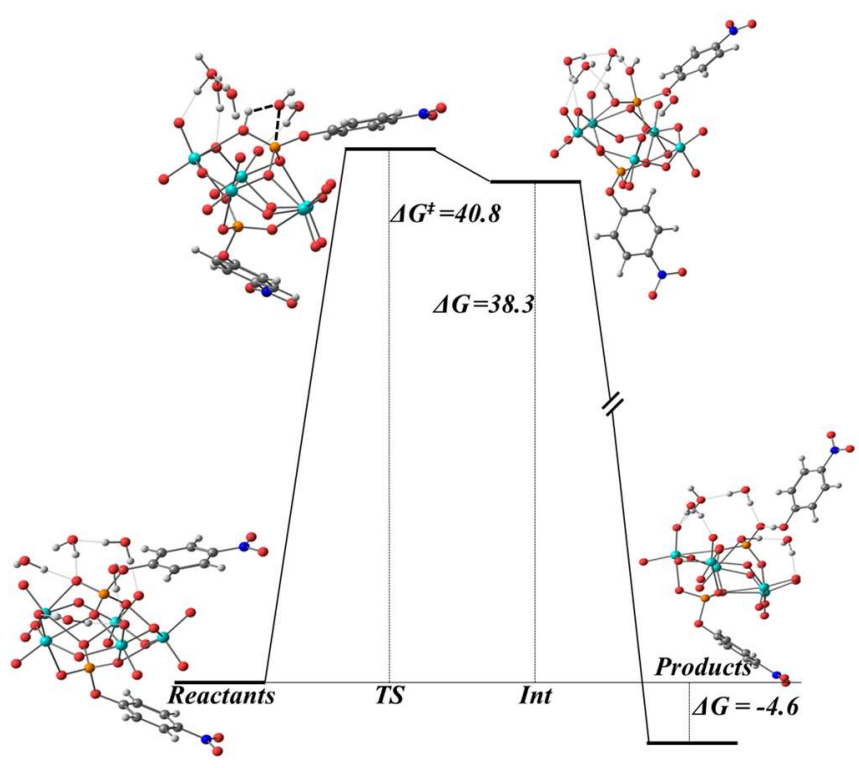

Figure 6. Reaction scheme for pNPP hydrolysis $\left[\mathrm{Mo}_{5} \mathrm{O}_{15}(\mathrm{pNPP})_{2}\left(\mathrm{H}_{2} \mathrm{O}\right)_{6}\right]^{6-}$. Gibbs free energies in $\mathrm{kcal} \mathrm{mol}^{-1}$.

The results of the hydrolysed activation with $\left\{\mathrm{Mo}_{2}\right\}$ are presented in Figure 8 along with the activation barrier height. When comparing these values to the non-catalysed pathways shown in Figure 5 a more favourable kinetics scenario is observed. The decrease in the barrier height is now down to $8.8 \mathrm{kcal} \mathrm{mol}^{-1}, 21$ $\mathrm{kcal} \mathrm{mol}{ }^{-1}$ below the threshold of the substrate assisted pathway and $13 \mathrm{kcal} \mathrm{mol}^{-1}$ below that of the solvent assisted mechanism. This stabilization of the transition state could be explained because of the stabilizing hydrogen bond interactions between the $\mathrm{H}$ atoms of the $\mathrm{O}$ bridge and the $\mathrm{O}$ atom in para to the $-\mathrm{NO}_{2}$ in the NPP species. Moreover, the product free energies are negative (exergonic), whereas those in Figure 5 are positive (endergonic, solvent-assisted mechanism) or thermoneutral (the substrate-assisted mechanism). Thus, we can affirm that the isomer of $\left\{\mathrm{Mo}_{2}\right\}$ dimer in which the $\mathrm{O}$ atoms of the bridge are protonated along with the axial $\mathrm{O}$ atoms produces a real catalytic effect on the hydrolysis of the phosphoester bond.
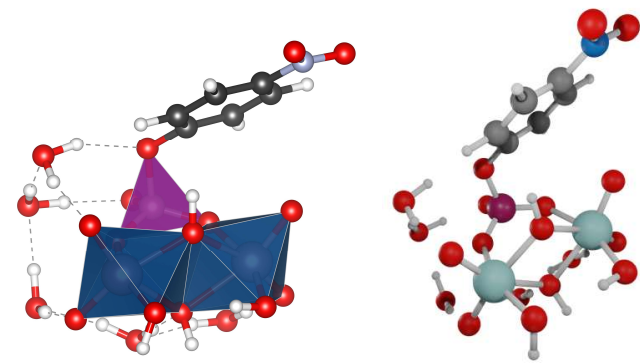

Figure 7. Optimised structure for the dimeric species observed through MS experiments along with the water molecule responsible for the hydrolysis of the substrate.

The $\left\{\mathrm{Mo}_{2}\right\}$ species is shown to increase the hydrolysis rate. A quasilinear transition state $\left(\mathrm{OPO} \sim 173.6^{\circ}\right)$ was obtained for all the compounds. This highlights the importance of the specific interactions of the water molecules in the mechanism. Not only all the activation energies $\left(\Delta G^{\ddagger}\right)$ are lower than that obtained for the uncatalyzed reaction but also the hydrolysis of the dimer is somewhat exergonic, whereas for the uncatalyzed reaction it is endergonic for the solvent assisted mechanism, and thermoneutral for the substrate assisted pathway.

Although the transition state associated to the $\left\{\mathrm{Mo}_{2}\right\}$ dimeric species with two edge-sharing octahedra capped with equatorial hydroxy groups is $16.4 \mathrm{kcal} \mathrm{mol}^{-1}$ lower in energy than that of the non-catalysed substrate assisted mechanism (see Supporting Information), comparing it to the transition state of the noncatalysed solvent assisted pathway this difference is only $8 \mathrm{kcal}$ $\mathrm{mol}^{-1}$.

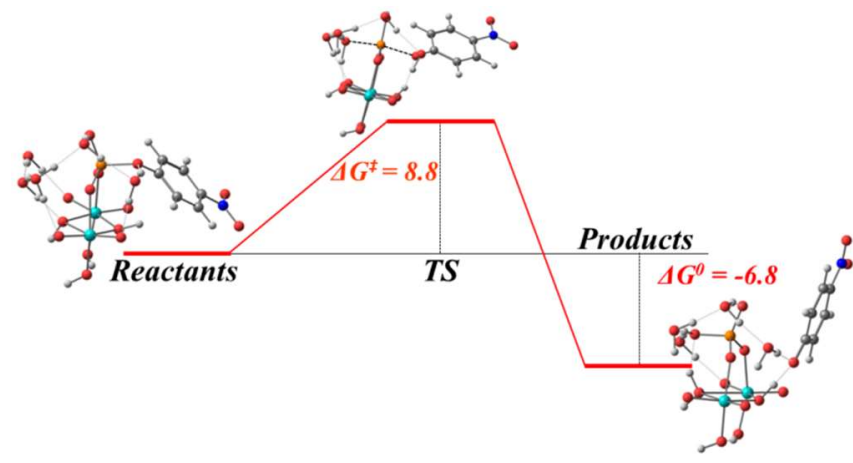

Figure 8. Reaction scheme for $p$ NPP hydrolysis activated by the $\left[\mathrm{Mo}_{2} \mathrm{O}_{8} \mathrm{H}_{4}\right]^{0}$ species in which the $\mathrm{O}$ bridge atoms are protonated along with the axial $\mathrm{O}$ atoms. Four explicit water molecules are considered. Gibbs energies are in kcal $\mathrm{mol}^{-1}$. 
The free energy changes of the overall transformations are summarised below:

$$
\begin{array}{r}
\text { A) } 8 \mathrm{H}_{3} \mathrm{O}^{+}+\left[\mathrm{Mo}_{7} \mathrm{O}_{24}\right]^{6-} \rightarrow 2\left[\mathrm{Mo}_{2} \mathrm{O}_{8} \mathrm{H}_{4}\right]+\left[\mathrm{MO}_{3} \mathrm{O}_{8}\right]^{2+}+ \\
\begin{aligned}
\Delta \mathrm{H}_{2} \mathrm{O} \\
\Delta \mathrm{G}^{\ominus}=-81.3 \mathrm{kcal} \mathrm{mol}{ }^{-1} \\
\text { B) } 2\left[\mathrm{Mo}_{2} \mathrm{O}_{8} \mathrm{H}_{4}\right]+\left[\mathrm{Mo}_{3} \mathrm{O}_{8}\right]^{2+}+8 \mathrm{H}_{2} \mathrm{O} \rightarrow\left[\mathrm{Mo}_{2} \mathrm{O}_{8} \mathrm{H}_{4}\right]+\mathrm{Mo}_{5} \mathrm{O}_{15}+7 \mathrm{H}_{2} \mathrm{O}+2 \mathrm{H}_{3} \mathrm{O}^{+} \\
\Delta \mathrm{G}^{\ominus}=-79.3 \mathrm{kcal} \mathrm{mol}{ }^{-1}
\end{aligned}
\end{array}
$$

C) $8 \mathrm{H}_{3} \mathrm{O}^{+}+\left[\mathrm{Mo}_{7} \mathrm{O}_{24}\right]^{6-} \rightarrow\left[\mathrm{Mo}_{2} \mathrm{O}_{8} \mathrm{H}_{4}\right]+\mathrm{Mo}_{5} \mathrm{O}_{15}+7 \mathrm{H}_{2} \mathrm{O}+2 \mathrm{H}_{3} \mathrm{O}^{+}$

$$
\Delta \mathrm{G}^{\ominus}=-160.6 \mathrm{kcal} \mathrm{mol}^{-1}
$$

\section{Probing for activity in analogous tungsten species}

The same calculations were repeated for tungsten analogues. A comparison of results between both metals is compiled in Table 2. The results showed in general higher activation barriers for the same reactions with tungsten analogues. The effect of the addition of explicit water molecules in the calculation was studied for the tungsten dimer as well. Comparative results can be found in the supporting information documents. The results are in agreement with previous studies with Mo systems in which the inclusion of explicit solvent molecules had a relevant effect in reaction barriers of phosphoester hydrolysis. We observe a general decrease in $\Delta \mathrm{G}^{\ddagger}$ with the inclusion of additional explicit molecules for both metal dimers. The data are also in agreement with the observations by Parac-Vogt et al. that found no catalytic activity for the tungsten analogue $\left[\mathrm{W}_{7} \mathrm{O}_{24}\right]^{6-}$, as the activation barriers are higher for $\left\{\mathrm{W}_{2}\right\}$ species than for Mo analogues and the general thermodynamic

\begin{tabular}{|c|c|c|c|c|}
\hline $\begin{array}{l}\text { No catalyst } \\
\text { substrate } \\
\text { assisted }\end{array}$ & \multicolumn{2}{|r|}{+29.8} & \multicolumn{2}{|c|}{+0.6} \\
\hline $\begin{array}{l}\text { No catalyst } \\
\text { solvent } \\
\text { assisted }\end{array}$ & & +21.4 & & \\
\hline Species $^{[a]}$ & $\begin{array}{l}\Delta \mathrm{G}^{\ddagger} \mathrm{Mo} \\
\mathrm{kcal} \mathrm{mol}{ }^{-1}\end{array}$ & $\begin{array}{l}\Delta \mathrm{G}^{\ddagger} \mathrm{W} / \mathrm{kcal} \\
\mathrm{mol}^{-1}\end{array}$ & $\begin{array}{l}\Delta \mathrm{G}^{\ominus} \mathrm{Mo} / \mathrm{kcal} \\
\mathrm{mol}^{-1}\end{array}$ & $\begin{array}{l}\Delta \mathrm{G}^{\ominus} \mathrm{W} / \mathrm{kcal} \\
\mathrm{mol}^{-1}\end{array}$ \\
\hline$\left\{M_{5}\right\}$ & +44.1 & +44.6 & -3.6 & -2.0 \\
\hline $\begin{array}{l}\left\{\mathrm{M}_{2}\right\} \\
\text { including } 4 \\
\text { explicit } \mathrm{H}_{2} \mathrm{O} \\
\text { molecules }\end{array}$ & +8.8 & +14.6 & -6.8 & -1.1 \\
\hline
\end{tabular}
equilibrium is less favourable.

Table 2. Activation and equilibrium free energies $\left(\Delta \mathrm{G}^{\ddagger}\right.$ and $\left.\Delta \mathrm{G}^{\odot} / \mathrm{kcal} \mathrm{mol}^{-1}\right)$ of pNPP hydrolysis.

$\Delta \mathrm{G}^{\ddagger} / \mathrm{kcal} \mathrm{mol}^{-1} \quad \Delta \mathrm{G}^{\odot} / \mathrm{kcal} \mathrm{mol}^{-1}$

\section{Conclusion}

A theory - experiment combined approach was employed in order to elucidate the underlying hydrolysis mechanism of POM-catalyzed DNA-model pNPP. The original work by ParacVogt et. al. proposed the activation of the phosphate group by a pentanuclear $\left\{\mathrm{Mo}_{5}-\mathrm{pNPP}\right\}$ precursor. We have shown that this is inconsistent with the results reported in this work. The catalytically active species responsible for the hydrolytic process is most likely to be the dimeric unit $\left[\mathrm{Mo}_{2} \mathrm{O}_{4}(\mathrm{OH})_{4}(\mathrm{pNPP})\right]^{2-}$, which exhibits a lower reaction barrier $\left(+8.8 \mathrm{kcal} \mathrm{mol}^{-1}\right)$ in a more exergonic reaction $\left(-6.8 \mathrm{kcal}^{\mathrm{mol}}{ }^{-1}\right)$ than the uncatalyzed one in marked contrast to the $\left\{\mathrm{Mo}_{5}\right\}$ alternative which was shown to have unfavourable free energies. Furthermore, no actual adducts between $\left\{\mathrm{Mo}_{5}\right\}$ and pNPP were detected in the ESI-MS spectra. In combination with the obtained computational data, it is likely that the formation equilibrium of $\left\{\mathrm{Mo}_{7}\right\}$ with smaller fragments such as $\left\{\mathrm{Mo}_{3}\right\}$ and $\left\{\mathrm{Mo}_{2}\right\}$ and their subsequent reassembly is the source of the hydrolytic activation rather than a rearrangement of the $\left\{\mathrm{Mo}_{5}\right\}$ framework.

Finally, we also studied the analogous pathway for the $\left\{\mathrm{W}_{5}\right\}$ and $\left\{W_{2}\right\}$ species and we found that the activation energies for the hydrolytic process are higher than the ones observed for the Mo congeners. The experiments described previously ${ }^{27}$ also did not detect any catalytic activity in the presence of the tungsten analogue presumably due to the differing $\mathrm{pH}$ window required for the active species to form.

\section{Experimental Section}

\section{Computational Details}

DFT calculations were performed using the Amsterdam Density Functiona 2017.01 (ADF) program package. Geometry optimizations, without symmetry constraints, were performed resorting to a combination of the gradient corrections of Becke 1998 exchange functional and Perdew 1986 correlation functional as well as the latest version of Grimme dispersion correction (BP86-D3). Relativistic effects were treated with the Zero Order Regular Approximation (ZORA) Hamiltonian. The frozen core approximation was employed, thus, triple- $\zeta$ Slater-type orbitals (STO) were used to describe the valence shells of $C$ and $N(2 s$ and $2 p)$. One polarization function was added to $\mathrm{C}, \mathrm{N}, \mathrm{O}, \mathrm{Mo}$ and $\mathrm{W}$ (single- $\zeta, 3 \mathrm{~d}, 4 \mathrm{f}$ ). Triple- $\zeta$ STOs were used to describe the valence shells of $H$ (1s) augmented with one polarization function (single- $\zeta, 2 s, 2 p)$. Solvent effects were treated with the Conductor-like Screening Model (COSMO) of solvation (Water, $\varepsilon=78.39$ ). Analytical frequencies were calculated to characterise the obtained stationary points and calculate the free energies (standard state $\mathrm{T}=298.15 \mathrm{~K}, \mathrm{P}=1 \mathrm{~atm}$ ). Transition states were followed after a fractional displacement of the imaginary vibrational mode to both the reactant(s) and product(s). The starting structures were modelled after the reported $\left[\mathrm{Mo}_{7} \mathrm{O}_{24}\right]^{6-}$ and $\left[\mathrm{Mo}_{5} \mathrm{O}_{15}(\mathrm{pNPP})_{2}\right]^{4-}$ geometries. Molecular renderings were made with VESTA ${ }^{66}$ and Chemcraft ${ }^{67}$ Optimised structures were deposited in the iochem-bd database ${ }^{68}$ and may be visualised at the following link https://dx.doi.org/10.19061/iochem-bd-6-70.

\section{ESI experimental}

All MS data were collected using a Q-trap, time-of-flight MS (Maxis Impact MS) instrument supplied by Bruker Daltonics Ltd. The detector was a timeof-flight, micro-channel plate detector and all data was processed using the Bruker Daltonics Data Analysis 4.1 software, whilst simulated isotope patterns were investigated using Bruker Isotope Pattern software and Molecular Weight Calculator 6.45. The calibration solution used was Agilent ES tuning mix solution, Recorder No. G2421A, enabling calibration between approximately $100 \mathrm{~m} / \mathrm{z}$ and $3000 \mathrm{~m} / \mathrm{z}$. This solution was diluted 60:1 with $\mathrm{MeCN}$. Samples were dissolved in $\mathrm{MeOH}$ and introduced into the MS via direct injection at $180 \mu \mathrm{L} \mathrm{h}^{-1}$. The ion polarity for all MS scans recorded was negative, at $180{ }^{\circ} \mathrm{C}$, with the voltage of the capillary tip set at $4000 \mathrm{~V}$, end plate offset at $-500 \mathrm{~V}$, funnel $1 \mathrm{RF}$ at $300 \mathrm{Vpp}$ and funnel 2 RF at $400 \mathrm{Vpp}$

\section{Acknowledgements}

This research was financially supported by the Fundação para a Ciência e a Tecnologia (FCT) by means of the project PTDC/QUIQFI/29236/2017, UID/MULTI/00612/2019, UID/MULTI/04046/2019, 
UIDB/04046/2020, UIDP/04046/2020 and by the Spanish Ministry of Economy, Industry and Competitiveness under the Maria de Maeztu Units of Excellence Programme - MDM-2016-0618. A.G. is thankful to Diputación Foral de Gipuzkoa for current funding in the frame of Gipuzkoa Fellows Program. HNM thanks the University of Glasgow. Dr Ángel Sánchez is grateful to Prof. Francisco Fernandez for fruitful discussions. This research was also funded by Eusko Jaurlaritza (the Basque Government), through Consolidated Group Project No. IT1254-19, and the Spanish MINECO/FEDER Project No. PGC2018097529-B-100. Technical and human support provided by IZO-SGI, SGIker (UPV/EHU, MICINN, GV/EJ, ERDF and ESF) is gratefully acknowledged.

Keywords: polyoxometalate - phosphoester hydrolysis - DFT • DNA • Artificial phophoesterases

[1] P. Gouzerh and M. Che, L'Act. Chim. 2006, 298, 9-22.

[2] N. N. Greenwood and A. Earnshaw in Chemistry of the Elements (2 ${ }^{\text {nd }}$ ed.), Oxford: Butterworth-Heinemann, 1997.

[3] P. Miró, S. Pierrefixe, M. Gicquel, A. Gil, C. Bo, J. Am. Chem. Soc. 2010, 132, 17787-17794.

[4] A. Gil, D. Karhánek, P Miró, M. R. Antonio, M. Nyman, C. Bo, Chem. Eur. J. 2012, 18, 8340-8346.

[5] E. Tiferet, A. Gil, C. Bo, T. Y. Shvareva, M. Nyman, A. Navrotsky, Chem. Eur. J. 2014, 20, 3646-3651.

[6] P. Miró, B. Vlaisavljevich, A. Gil, P. C. Burns, M. Nyman, C. Bo, Chem. Eur. J. 2016, 22, 8571-8578.

[7] P. Yang, T. Ma, Z. Lang, S. Misirlic-Dencic, A. M. Isakovic, A. Bénvei, M. B. Čolović, I. Markovic, D. Z. Krstić, J. M. Poblet, Z. Lin, U. Kortz, Inorg. Chem. 2019, 58, 11294-11299.

[8] W. W. Ayass, T. Fodor, Z. Lin, R. M. Smith, X. Xing, K. Abdallah, I. Tóth, L. Zékány, M. Pascual-Borràs, A. Rodríguez-fortea, J. M. Poblet, L. Fan, J. Cao, B. Keita, M. S. Ulrich, U. Kortz, Inorg. Chem. 2016, 55, 1011810121.

[9] A. Hiskia, A. Troupis, S. Antonaraki, E. Gkika, P. Kormali, E. Papaconstantinou, Int. J. Env. Anal. Chem. 2006, 86, 233-242.

[10] C. Busche, L. Vilà-Nadal, J. Yan, H. N. Miras, D. L. Long, V. P. Georgiev, A. Asenov, R. H. Pedersen, N. Gadegaard, M. M. Mirza, D. J. Paul, J. M. Poblet, L. Cronin, Nature 2014, 515, 545-549.

[11] J. Lehmann, A. Gaita-Ariño, E. Coronado, D. Loss, Nanotechnology 2007, 2, 312-317.

[12] H. I. Buvailo, V. G. Makhankova, V. N. Kokozay, I. V. Omelchenko, S. V. Shishkina, J. Jezierska, M. V. Pavliuk, S. I. Shylin, Inorg. Chem. Front. 2019, 6, 1813-1823.

[13] J. T. Rhule, C. L. Hill, D. A. Judd, R. F. Schinazi, Chem. Rev. 1998, 98, 327-358.

[14] B. Hasenknopt, Front Biosci. 2005, 10, 275-287.

[15] Y. Toshihiro in Polyoxometalates for Molecular Devices: Antitumor Activity and Luminescence (Eds.: M. Pope and A. Müller) Polyoxometalates: From Platonic Solids to Anti-Retroviral Activity Springer 1994, pp. 337-358.

[16] X. Wang, J. Liu, J. Li, Y. Yang, J. Liu, B. Li, M. T. Pope, J. Inorg. Biochem. 2003, 94, 279-284.

[17] J. Li, Y. Qi, J. Li, H. Wang, X. Wu, L. Duan, E. Wang, J. Coord. Chem. 2004, 57, 1309-1319.

[18] H. U. Gerth, A. Rompel, B. Krebs, J. Boos, C. Lanvers-Kaminsky, AntiCancer Drugs 2005, 16, 101-106.

[19] X. Wang, F. Li, S. Liu, M. T. Pope, J. Inorg. Biochem. 2005, 99, 452-457.

[20] A. Ogata, S. Mitsui, H. Yanagie, H. Kasano, T. Hisa, T. Yamase, M. Eriguchi, Biomed. Parmacother. 2005, 59, 240-244.

[21] A. Bijelic, M. Aureliano, A. Rompel, Angew. Chem. Int. Ed. 2018, 58, 2980-2999.

[22] A. Bijelic, M. Aureliano, A. Rompel, Chem. Commun. 2018, 54, 11531169.

[23] T. Ma, P. Yang, I. Damman, Z. Lin, A. S. Mougharbel, M.-X. Li, F. Adăscălitei, R. Mitea, C. Silvestru, C. Thorstenson, M. S. Ulrich, K. Cseh, M. A. Jakupec, B. K. Keppler, M. Donalisio, R. Cavalli, D. Lembo, U. Kortz, Inorg. Chem. 2020, 59, 2978-2987.

[24] A. Radzicka and R. Wolfenden, Science 1995, 267, 90-93.

[25] C. M. Tomé, M. C. Oliveira, M. Pillinger, I. S. Gonçalves, M. Abrantes, Dalton Trans. 2013, 42, 3901-3907.

[26] B. Alberts in Molecular Biology of the Cell (6 ed.) Garland Science 2017.
[27] E. Cartuyvels, G. Absillis, T. N. Parac-Vogt, Chem. Commun. 2008, 1, 85-87.

[28] L. Van Lokeren, E. Cartuyvels, G. Absillis, R. Willem, T. N. Parac-Vogt, Chem. Commun. 2008, 24, 2774-2776.

[29] E. Cartuyvels, K. Van Hecke, L. Van Meervelt, C. Goerller-Walrand, T. N. Parac-Vogt, Inorg. Biochem. 2008, 102, 1589-1598.

[30] G. Absillis, E. Cartuyvels, R. Van Deun, T. N. Parac-Vogt, J. Am. Chem Soc. 2008, 130, 17400-17408.

[31] G. Absillis, R. Van Deun, T. N. Parac- Vogt, Inorg. Chem. 2011, 50 , 11552-11560.

[32] S. Vanhaecht, G. Absillis, T. N. Parac-Vogt, Dalton Trans. 2012, 41 10028-10034.

[33] W. Li, T. Rudack, K. Gerwert, F. Gräter, J. Schlitter, J. Chem. Theory Comput. 2012, 8, 3596-3604.

[34] P. Nunes, A. C. Gomes, M. Pillinger, I. S. Gonçalves, M. Abrantes, Micropor. Mesopor. Mat. 2015, 208, 21-29.

[35] A. C. Gomes, C. A. Gamelas, J. A. Fernandes, F. A. Almeida, P. Nunes, M. Pillinger, I. S. Gonçalves, C. C. Romão, M. Abrantes, Eur. J. Inorg. Chem. 2014, 2014, 3681-3689.

[36] A. C. Gomes, M. Pillinger, P. Nunes, I. S. Gonçalves, M. Abrantes, J. Organomet. Chem. 2014, 760, 42-47.

[37] L. Lain, H. Lönnberg, T. Lönnberg, Chem. Eur. J. 2013, 19, 12424 12434.

[38] P. Das, N. B. Chandar, S. Chourey, H. Agarwalla, B. Ganguly, A. Das, Inorg. Chem. 2013, 52, 11034-11041.

[39] T. K. N. Luong, G. Absillis, P. Shestakova, T. N. Parac-Vogt, Eur. J. Inorg. Chem. 2014, 2014, 5276-5284.

[40] T. K. N. Luong, G. Absillis, P. Shestakova, T. N. Parac-Vogt, Dalton Trans. 2015, 44, 15690-15696.

[41] T. K. N. Luong, P. Shestakova, T. T. Mihaylov, G. Absillis, K. Pierloot, T. N. Parac-Vogt, Chem. Eur. J. 2015, 21, 4428-4439.

[42] E. Gouré, M. Carboni, A. Troussier, C. Lebrun, J. Pécaut, J. F. Jacquot, P. Dubourdeaux, M. Clémancey, G. Blondin, J. M. Latour, Chem. Eur. J. 2015, 21, 8064-8068.

[43] T. K. N. Luong, P. Shestakova, T. N. Parac-Vogt, Dalton Trans. 2016 45, 12174-12180.

[44] S. Bosch, P. Comba, L. R. Gahan, G. Schenk, J. Inorg. Biochem. 2016 162, 343-355.

[45] B. Kandasamy, S. Vanhaecht, F. M. Nkala, T. Beelen, B. S. Bassil, T. N Parac-Vogt, U. Kortz, Inorg. Chem. 2016, 55, 9204-9211.

[46] T. K. N. Luong, T. T. Mihaylov, G. Absillis, P. Shestakova, K. Pierloot, T. N. Parac-Vogt, Inorg. Chem. 2016, 55, 9898-9911.

[47] T. K. N. Luong, I. Govaerts, J. Robben, P. Shestakova, T. N. Parac-Vogt, Chem. Commun. 2017, 53, 617-620.

[48] A. De, S. Pradhan, S. Sitangshu, B. Biswas, J. Indian Chem. Soc, 2017, 94, 1063-1071.

[49] X.-L. Huang, Astrobiology 2018, 18, 294-310.

[50] Q. Hu, V. M. Jayasinghe-Arachchige, J. Zuchniarz, R. Prabhakar, Front.Chem. 2019, 7, 195.

[51] H. Kou, Y. Wang, P. Ding, J. Li, B. Shi, J. Coord. Chem. 2019, 72, 1683 1696.

[52] C. Pereira, G. Farias, F. G. Maranha, N. Castilho, G. Schenk, B. de Souza, H. Terenzi, A. Neves, R. A. Peralta, J. Biol. Inorg. 2019, 24, 675691.

[53] Q. Hu, V. M. Jayasinghe-Arachchige, G. Sharma, L. F. Serafim, T. J. Paul, R. Prabhakar, Wiley Interdiscip. Rev. Comput. Mol. Sci. 2020, DOI https://doi.org/10.1002/wcms.1466

[54] J. R. Morrow and W. C. Trogler, Inorg. Chem. 1988, 27, 3387-3394.

[55] T. Koike and E. Kimura, J. Am. Chem. Soc. 1991, 113, 8935-8941.

[56] S. Amin, D. A. Voss Jr., W. D. Horrocks Jr., J. R. Morrow, Inorg. Chem. 1996, 35, 7466-7467.

[57] S. Amin, D. A. Voss Jr., W. D. Horrocks Jr., C. H. Lake, M. R. Churchill, J. R. Morrow, Inorg. Chem. 1995, 34, 3294-3300.

[58] K. O. A. Chin, J. R. Morrow, Inorg. Chem. 1994, 33, 5036-5041.

[59] H. N. Miras, D. Stone, D. L. Long, E. J. L. Mclnnes, P. Kögerler, L. Cronin, Inorg. Chem. 2011, 50, 8384-8391.

[60] E. F. Wilson, H. N. Miras, M. H. Rosnes, L. Cronin, Angew. Chem. - Int Ed. 2011, 50, 3720-3724.

[61] H. Zang, A. Surman, D. Long, L. Cronin, H. N. Miras, Chem. Commun. 2016, 52, 9109-9112.

[62] H. Y. Zang, J. J. Chen, D. L. Long, L. Cronin, H. N. Miras, Adv. Mater 2013, 25, 6245-6249. 
[63] L. Pettersson, I. Andersson, L.-O.Öhman, Inorg. Chem. 1986, 25, 47264733.

[64] J. Fischer, L. Ricard, P. Toledano, J. Chem. Soc. Dalton Trans. 1974 941-946.

[65] F. Duarte, J. Åqvist, N. H. Williams, S. C. L. Kamerlin, J. Am. Chem. Soc. 2015, 137, 1081-1093.

[66] K. Momma, F. Izumi, J. Appl. Crystallogr. 2011, 44, 1272-1276.

[67] http://www.chemcraftprog.com.

[68] M. Álvarez-Moreno, C. de Graaf, N. López, F. Maseras, J. M. Poblet, C. Bo, J. Chem. Inf. Model. 2015, 55, 95-103. 
